\title{
An Overview of Phytochemical and Pharmacological Potentials of Punica granatum L
}

\author{
Janani Jacob ${ }^{1, *}$, Rajiv P2 $^{2}$, Gopalan $\mathbf{R}^{3}$, Lakshmanaperumalsamy $\mathbf{P}^{4}$
}

Janani Jacob ${ }^{1, *}$,

Rajiv P2, Gopalan $\mathbf{R}^{3}$,

Lakshmanaperumalsamy $\mathrm{P}^{4}$

${ }^{1}$ Research Scholar, Karpagam Academy of Higher Education, Coimbatore-641021, INDIA.

${ }^{2}$ Assistant Professor, Department of Biotechnology, Karpagam Academy of Higher Education, Coimbatore-641021, INDIA.

${ }^{3}$ Head and Professor, Department of Botany, Karpagam Academy of Higher Education, Coimbatore-641021, INDIA. ${ }^{4}$ Former Registrar, Karpagam Academy of Higher Education, Coimbatore-641021,

INDIA.

\section{Correspondence}

\section{Janani Jacob}

Research Scholar, Karpagam Academy of Higher Education, Coimbatore-641 021, INDIA.

Phone no: 91-9487072453

E-mail: janani@naturalremedy.com

History

- Submission Date: 12-12-2018;

- Review completed: 05-04-2019;

- Accepted Date: 18-04-2019.

DOI : 10.5530/pj.2019.11.181

Article Available online http://www.phcogj.com/v11/i5

Copyright

(C) 2019 Phcogj.Com. This is an openaccess article distributed under the terms of the Creative Commons Attribution 4.0 International license.

\section{ABSTRACT}

Pomegranate (Punica granatum) is considered as "A pharmacy unto itself" in Ayurvedic medicine and also used in several other systems of medicine. The plant belongs to the family Lythraceae containing pomegranate as a predominant species. Various parts of the plant exhibits significant pharmacological activities due to its wide range of potential bioactive compounds. Many biological activities proved its antioxidant, anticancer, anti-inflammatory, antimicrobial, anti- athersclerotic, antidiabetic actions and many more. This article provides a review of phytoconstituents of Punica granatum and its diverse array of biological properties. Key words: Punica granatum, Phytoconstituents, Pharmacological activities, Traditional medicine, Lythraceae, Bioactive compounds.

\section{INTRODUCTION}

Plants are thought to be a significant source of medicinal components. ${ }^{1}$ Plants with medicinal values play a vital role in developing therapeutic drugs which are utilized in the indigenous system of medicine as described in ancient literature. ${ }^{2}$ Plants are an excellent source of new bioactive compounds, because of which an interest for phytomedicinal sector is developing rapidly. ${ }^{3}$

As a result of phytochemical investigation, around $74 \%$ of drugs of plant origin were identified and isolated for their traditional medicinal use. ${ }^{4}$ Being a potential source, natural products act as primary ingredient in drug development. ${ }^{5}$

Medicinal plants are the main source for traditional medicine, herbal medicine and various dietary supplements. ${ }^{6}$ Currently, plants are considered to be the cheapest source of medicine used by the major population of the globe, considered as safe with less or no side effects.?

\section{CLASSIFICATION}

Kingdom: Plantae

Division: Magnoliophyta

Class: Magnoliopsida

Order: Myrtales

Family: Lythraceae

Genus: Punica

Species: P. granatum

Punica granatum was formerly classified under a separate family Punicaceae and recently included in Lythraceae family. The family contains genus Punica with two species Punica granatum, commonly known as Pomegranate- the predominant species and Punica protopunica the less predominant species found typically in the island of Socotra. ${ }^{7}$ The plant is distributed throughout the world believed to be native to Iran and the Himalayan region. ${ }^{8}$ The fruit of this plant is known as nature's power fruit. The plant is an evergreen shrub, with multiple tiny stems. It commonly grows up to $1.8-4.6 \mathrm{~m}$ height. P. granatum is found to have deciduous and shiny leaves which are around $7.6 \mathrm{~cm}$ long. The flowers are $5 \mathrm{~cm}$ long normally double trumpet-shaped orangered ruffled petals and seen throughout the summer. The fruit is globose with a tough leathery skin with a diameter of around $5-7.6 \mathrm{~cm}$. The mature fruit has reddish or yellowish green shiny skin. The fruit is known as a berry which is composed of spongy membranous walls which contains reddish or whitish pulp with crunchy seeds. The seeds represent around $52 \%$ of the entire mass of the fruit. ${ }^{7-10}$

Anatomically, $P$. granatum can be divided into different parts like seed, juice, peel, leaf, flower, bark and root which exhibits significant pharmacological properties. ${ }^{11}$

P. granatum is used in different systems of medicine for treating a variety of ailments in humans. In the Ayurvedic system of medicine the plant is known as "A pharmacy unto itself" which is used as an antiparasitic agent, blood tonic and medicine for diarrhea and ulcers. In the Unani system of medicine, pomegranate is used in the treatment of diabetes and is practiced in the Middle East and India. ${ }^{12-14}$

P.granatum has a wide range of therapeutic properties against various illnesses and helps in the treatment and prevention of cancer, cardiovascular diseases, diabetes, dental conditions and offers protection against (UV) radiation. Its other significant applications include infant brain ischemia, Alzheimer's disease, male infertility, arthritis and obesity. ${ }^{15-19}$

In many countries pomegranate has been utilized in herbal remedies where the entire fruit, peels and roots and various other parts of the plants have been used. In the traditional system of medicine, the 
peels of pomegranate have been used in the treatment of diarrhea and dysentery. ${ }^{20-23}$

\section{CHEMICAL CONSTITUENTS AND COMPONENTS}

The chemical composition of the fruit and other plant parts is influenced by climate, geographical area, storage and cultivars. Punicalagin, punicalin, ellagic acid and ellagic acid derivatives such as 3,3'-di-O-methylellagic acid, 3,3'-tri- $O$-methylellagic acid, 3'-Omethyl-3,4-methylene, flavonoids like luteolin, quercetin, kaempferol and anthocyanins (delphinidin, cyanidin and pelargonidin), phenolic compounds such as pedunculagin, punicacortein A-D, granatin A and $\mathrm{B}$, punicafolin, punigluconin, corilagin, gallocatechins, several fatty acids, sterols, triterpenes and other tannins have been identified and isolated from various parts of the plant which possess an array of therapeutic properties. ${ }^{24-34}$

P. granatum juice contains anthocyanins, glucose, ascorbic acid, ellagic acid, gallic acid, caffeic acid, catechin, epigallocatechin gallate, quercetin, rutin, iron and aminoacids. Punicic acid and sterols are also found in the seed oil of pomegranate. The fruit rind of the plant contains punicalagin, flavones, flavonones and other flavanols. The leaves are found to contain tannins such as punicalin and punicafolin and flavone glycosides like luteolin and apigenin, considered to be the important constituent of P. granatum. The flowers of pomegranate contain Ursolic acid, triterpinoids and Asiatic acid, the roots and barks ellagitannins and piperdine alkaloids.

Around $16 \%$ of an individual's daily requirement such as vitamin $\mathrm{C}$, vitamin $\mathrm{B} 5$, potassium and natural phenols like ellagitannins and flavonoids are also present in the aril juice of pomegranate. ${ }^{35}$

\section{PHARMACOLOGICAL ACTIVITIES}

\section{Antioxidant activity}

Four different in vitro testing methods were used to demonstrate that the juice and seed extracts of pomegranate exhibited 2 to 3 times the antioxidant activity of either green tea or red wine. ${ }^{30}$ Free radical scavenging, decrease in macrophage oxidative stress and lipid per oxidation in animals were shown by the extract of P. granatum including plasma antioxidant capacity in elderly humans. ${ }^{36}$ Pomegranate possessed the best antioxidant activity, independent of the antioxidant between phenolics concentration and antioxidant capacity. ${ }^{37}$ Research on rats and mice showed that by- product extract of pomegranate whole fruits reduced $19 \%$ oxidative stress in peritoneal macrophages, $42 \%$ decrease in cellular lipid peroxide content and $53 \%$ increase in reduced glutathione levels. ${ }^{36}$

A study confirms that the juice of pomegranate pulp shows higher antioxidant capacity in comparison with apple juice. An increase in plasma antioxidant capacity from 1 to $1.46 \mathrm{mmol}$ was observed when using Ferric Reducing Antioxidant Power assay (FRAP assay), when $250 \mathrm{ml}$ of juice of pomegranate pulp given daily for a period of 4 weeks to the elderly healthy subjects. ${ }^{38}$

The results of DPPH test, 5- lipoxygenase assay and luminal/ xantine/ xantine oxidase assay reveal that arils, juice and rinds of pomegranate show higher antioxidant activity when compared to aqueous and ethyl acetate extracts. ${ }^{39}$

\section{Anticancer}

Different plant parts of $P$. granatum like fruit, juice, seed and seed oil works on prostate, blood, skin, colon, lung, oral and leukaemia cancers. Ellagic acid is an important Phytochemical in pomegranate and the seed oil is effective against various cancers including prostate, blood, skin, colon, lung, oral, oesophagus, bladder and leukaemia cancers. ${ }^{40}$ The results of in vitro cell cultures and animal studies, as well as the existing data, show that breast cancer can be prevented by the anticancer activity of pomegranate. ${ }^{41}$ Organ culture model of mouse breast cancer demonstrates that the pomegranate seed oil is capable of blocking the development of breast cancer ${ }^{[43]}$. Pomegranate seed oil helps in inhibiting the proliferation of prostate cancer lines by changing the cell growth cycle. ${ }^{42}$

\section{Antimicrobial}

The alcohol extracts of the fruits of $P$. granatum exhibited significant antibacterial activity against S.aureus, E.coli and Shigella dysentriae. ${ }^{20}$ Results of studies reveal that punicalagin, major hydrolysable tannin found in the pomegranate possesses antimicrobial activity against Candida albicans. ${ }^{43}$ The fruit rind of pomegranate inhibits the growth of Penicillium citirnum, P. patulum, P. ruqufortii and Aspergillus achraceous with various test organisms when tested for its fungistatic activity. ${ }^{44}$

Extracts of $P$. granatum act as an antagonist against the microorganisms that are responsible for the urinary tract infection. Methanol extract shows activity against the multidrug resistant bacterial strains of the urinary infection samples. ${ }^{45-48}$ Research results show that the hydroalcohol extract of pomegranate may be used as a substitute for treating the dental plague bacteria by decreasing the number of colonyforming units per milliliter by $84 \%$ compared to control groups that offer only $11 \%$ reduction. ${ }^{49}$

\section{Antiflammatory}

An in vivo study shows that the extract of P. granatum effectively inhibits the inflammatory cytokine- induced production of PGE2 and nitric oxide..$^{50}$ An in vitro study results exhibit that the Cold pressed seed oil of $P$. granatum (CPSO) inhibits both cyclooxygenase and lipoxygenase enzymes. The enzyme Cyclooxygenase which is responsible for the conversion of arachidonic acid to prostaglandins is inhibited by the Cold pressed seed oil of P. granatum by $37 \%$ and helps by $75 \%$ in the inhibition of Lipoxygenase, which acts as a catalyst in the conversion of arachidonic acid. ${ }^{9}$

Cold pressed seed oil of pomegranate seeds is found to contain significant anti- inflammatory constituents such as polyphenols and fatty acids. These chemical constituents exhibit an inhibition of 31- 44\%, 69- $81 \%$ and $21-30 \%$ of sheep cyclooxygenase, soyabean lipozygenase and soyabean lipozygenase from fermented juice of the extract respectively. The polyphenols also is reported to suppress the inflammatory cell signaling in colon cancer cells. ${ }^{51}$

\section{Anti-athersclerotic activity}

Atherosclerosis may be prevented and suppressed by pomegranatederived products which possess anti-atherogenic effects. ${ }^{52-56}$ Antiantherogenic effects have been observed when pomegranate is taken for longer as well as shorter periods. Enhancement of oxidative status and reduction in lipid peroxidation were exhibited in the study when pomegranate juice was administered for a week with various dose levels. ${ }^{12,53,57}$

An attempt was made to identify the constituents of various parts of pomegranate which possessed anti-athersclerotic activity. Results reveal that the juice of pomegranate and the extract of the aerial parts are found to contain excellent content of anthocyanins and hydrolysable tannins act in the reduction serum oxidative stress in contrast peel extract of pomegranate which is effective on the extent of Ox-LDL uptake of macrophages and their oxidative status. ${ }^{56}$

Reduction in cholesterol level was found more effective by the juice of pomegranate when compared to the extracts of fruit peel..$^{54}$ 


\section{Alzheimer's disease}

Polyphenols present in pomegranate possess neuroprotective properties and were tested for Alzheimer's disease in an animal model. Pomegranate juice when given to transgenic mice with Alzheimer's kind of pathology, were observed to have $50 \%$ less accumulation of soluble amyloid-beta and hippocampal amyloid deposition that consumed sugar water. This study proves that pomegranate juice has neuroprotective activity. ${ }^{58}$

Cognitive disorders like dementia and Alzheimer's disease may be effectively treated with pomegranate. Ethanol extract of the seeds of pomegranate showed a significant cognitive activity on aged and scopolamine treated mice. Upon the chronic administration for 21 days of extract of $P$. granatum and vitamin C, a significant reverse was observed in the age induced or scopolamine induced retention deficits in both the paradigm. A significant reduction of lipid peroxidation level and increased antioxidant glutathione level were found in the tissues of the brain with the treatment of pomegranate extract. ${ }^{59}$

\section{Anti-diabetic activity}

The fruit rind extract of pomegranate exhibits an excellent-bloodsugar-lowering effect. It is suitable for prolonged use with low toxicity for metabolic syndrome and its related pathologies, obesity, type 2 diabetes and cardiovascular diseases. ${ }^{60}$

Research studies show that the increase in the blood sugar level is prevented when the Flower extract of $P$. granatum is supplemented for 6 weeks to the obese diabetic rats following a glucose- laden meal. There was no such activity found in normal rats. The extract of pomegranate flower also exhibits an enhancement in the gene expression of the vital transcription factor PPAR- gamma. This in turn helps in regulating the cellular responses enabling the heart of a diabetic animal to use the sugar energy better by its normalized expression of a glucose transporting protein in the heart muscle. ${ }^{61,62}$

In Unani and ayurvedic systems of medicine pomegranate flowers have been used for the diabetic treatment. Researchers conducted studies on the extract of pomegranate flowers investigated on serum lipid profile. ${ }^{63,64}$

\section{Dermatology}

Studies reveal that the fruit extract of $P$. granatum, standardized with punicalagins, shows significant protective effects against UVA and UVB induced damage in human skin fibroblast cells. The fruit extract of $P$. granatum is capable of protecting human skin fibroblast against UV exposure by decreasing the induction of the proinflammatory transcription factor NF-KappaB, a down regulation of pro-apoptotic caspase-3 and increasing G0/ G1 phase associated with DNA repair. ${ }^{65,66}$

\section{Other biological activities}

Tannins present in the pomegranate play a vital role in protecting people against gastric ulcer. ${ }^{67}$ Hydro alcoholic extract of $P$. granatum fruit which possesses antibacterial activity may be considered as an alternative in the treatment against dental plague bacteria. ${ }^{49}$

Aqueous and alcohol extract of the fruit peel of the plant has been reported for anti-diarrheal activity. Reports reveal that the extracts show remarkable activity in rats, when compared to loperamide hydrochloride which is used as an anti-diarrheal drug. ${ }^{68}$

\section{CONCLUSION}

Punica granatum is an ancient fruit with an illustrious medical history and has been the subject of classical review for over 100 years. Pomegranate contains a lot of potential therapeutic properties due to the presence of various classes of chemical constituents like tannins, alkaloids, glycosides, volatile oils, flavonoids and resins, gums. $P$. granatum has been reported with various pharmacoglogical activities like antioxidant, antimicrobial, antiviral, antidiabetic, anticancer, Alzheimer's disease, etc., due to the presence of bioactive compounds.

The indigenous or traditional system of medicine has become important in the field of medicine. The practitioners relying on medicinal plants for their primary healthcare needs. Herbal medicines are still being used primarily for historical and cultural reasons. This attempt is made to present an overview of phytochemical and pharmacological activities of plant Punica granatum.

\section{ACKNOWLEDGEMENT}

The authors would like to thank M/s. Natural Remedies Pvt. Ltd., Bengaluru, India.

\section{CONFLICTS OF INTEREST}

None.

\section{ABBREVIATIONS}

UV: Ultra violet; DPPH: 2,2-diphenyl-1-picrylhydrazyl; Ox-LDL: Oxidized low-density lipoprotein; UVA: Ultra violet A; UVB: Ultra violet B; DNA: Deoxyribonucleic acid.

\section{REFERENCES}

1. Penos G. Index plantarum medicinalium totius mundi eorumque synonymorum (EMPLED). Org. (Ed.) Med. Fram Nfilano. 1983;188-95.

2. Verma S, Singh SP. Current and future status of herbal medicines. Veterinary World Rev. 2008;1(11):347-50.

3. Douglas KA. Pharmacognosy in the 21st century. Journal of Pharmacy and Pharmacology. 2001;53(2):135-48.

4. Farnsworth NR, Soejarto DD. Global importance of medicinal plants. In Akerele O, Heywood V, Synge H (Eds.), The conservation of medicinal plants. Cambridge university press, Cambridge UK. 1991;25-51.

5. WHO. Traditional medicine: Growing needs and potentials. WHO policy perspectives on medicines. World Health Organization, Geneva. 2002;1-6.

6. Newman DJ, Cragg GM. Natural products as sources of new drugs over the last 25 years. J Nat Prod. 2007;70(3):461-77.

7. Kaewseejan N, Puangapronpitag D, Nakorniriab M. Evaluation of phytochemical composition and antibacterial property of Gynura procumbens extract. Asian Journal of Plant Sciences. 2012;11(2):77-82.

8. Middha SK, Usha T, Pande A. A review on antihyperglycemic and antihepatoprotective activity of eco-friendly Punica granatum peel waste. Evidence-Based Complementary and Alternative Medicine. 2013;1-10.

9. Akhlaghi M, Bandy B. Mechanisms of flavonoid protection against myocardial ischemia reperfusion injury. J Mol Cell Cardiol. 2009;46(3):309-17.

10. Quanis EY, Elokda AS, Ghalyun YY, Addulla FA. Antidiahorrhealactivity of the aqueous extract of Punica granatum peels. Pharm Biol. 2007;45(9):715-20.

11. Stover E, Mercure EW. The Pomegranate a new look at the fruit of paradise. Hort Sci. 2007;42(5):1088-92.

12. Aviram M, Dornfeld L. Pomegranate juice consumption inhibits serum angiotensin converting enzyme activity and release systolic pressure. Antherosclerosis. 2001;158(1):195-8.

13. Batra A, Mehta BK, Boladia MM. Fatty acid composition of Punica grantumseed oil. Acta Pharm Jugosl. 1968;3(1):63-6.

14. Batta AK, Rangaswami S. Crystalline chemical components of some vegetable drugs. Phytochemistry. 1973;12:214-6.

15. Lad V, Frawley D. The yoga of herbs. Lotus Press. 1986;135-6.

16. Caceres A, Giron LM, Alvarado SR, Torres MF. Screening of antimicrobial activity of plants popularly used in Guatemala for treatment of dermatomucosal diseases. J Ethnopharmacol. 1987;20(3):223-37.

17. Saxena A, Vikram NK. Role of selected Indian plants in management of type 2 diabetes: A review. J Altern Complement Med. 2004;10(2):369-8. 
18. Lansky EP, Newman R. Punica granatum and its potential for prevention and treatment of inflammation and cancer. J Ethnopharmacol. 2007;109(2):177-206.

19. Schubert SY, Lansky EP, Neeman I. Antioxidant and eicosanoid enzyme inhibition properties of pomegranate seed oil and fermented juice flavonoids. $J$ Ethnopharmacol. 1999;66(1):11-7.

20. Almad I, Beg AZ. Antimicrobial and phytochemical studies on 45 Indian medicinal plants against multi-drug resistant human pathogen. J Ethnopharmacol. $2001 ; 74(2): 113-23$.

21. Braga LC, Shupp JW, Cummings C, Jett M, Takahashi JA, Carmo LS, et al. Pomegranate extract inhibits Staphylococcus aureus growth and subsequent enterotoxin production. J Ethnopharmacol. 2005;96(1-2):335-9.

22. Voravuthikunchai S. Sririrak S, Limsuwan S, SupawitaT, lidaT, HondaT. Inhibitory effects of active compounds from Punica granatum pericarp on verocytotoxin production by enterohemorrhagic Escherichia coli 0157: H7. J Health Sci. 2005;51(5):590-6.

23. Reddy M, Gupta S, Jacob M, Khan S, Ferreira D. Antioxidant, antimalarial and antimicrobial activities of tannin rich fractions, ellagitannins and phenolic acid from Punica granatum L. Planta medica. 2007;73(5):461-7.

24. Malgerejo P, Salazar DM, Artes F. Organic acid and sugars composition of harvested pomegranate fruits. Eur J Res Technol. 2000;211(3):185-90.

25. Nanda SD, Rao VS, Krishnamurthy S. Effect on shrink film wrapping and storage temperature on the shelf life and quality of pomegranate fruits CV. Ganesh. Postharvest Biol Technol. 2001;22(1):61-9.

26. Barzegar M, Fadavi A, Azizi MH. An investigation on the physic-chemical composition of various pomegranates (Punica granatum L) grown in Yazd. Iranian. J Food Sci Technol. 2004;1(2):9-14.

27. Miguel G, Fontes C, Antunes D, Neves A, Martins D. Anthocyanin concentration of Assaria pomegranate fruits during different cold storage conditions. J Biomed Biotechnol. 2004;5:338-42.

28. Fadavi A, Barzegar M, Azizi MH, Bayat M. Physicochemical composition of ten pomegranate cultivars (Punica granatum) grown in Iran. Food Sci Technol Int. 2005; $11(2): 113-9$

29. Artik N. Determination of phenolic a compounds in pomegranate juice by HPLC. J Fruit Processing. 1998;8(2):492-9.

30. Tanaka T, Nonaka G, Nishioka I. Tannins and related compounds. XL. Revision of the structures of Punicalin and Punicalagin and isolation and characterization of 2-O-galloyl-punicalin from the bark of Punica grantum L. Chem Pharm Bull. 1986;34(2):650-5.

31. Tanaka T, Nonaka G, Nishioka I. Tannins and related compounds. XLI. Isolation and characterization of novel ellagitannins, Punica coreins $A, B, C$ and $D$ and punigluconin from the bark of Punica granatum L. Chem Pharm Bull. 1986;34(2):656-63.

32. Satomi H, Umemura K, Ueno A, Hatano T, Okuda T, Noro T. Carbonic anhydrase inhibition from the pericaps of Punica granatum L. Bio Pharm Bull. 1993;16(8):787-90.

33. Wang FR, Sie WD, Zhang Z, Xing DM, Ding Y, Wang W, et al. Bioactive compound from the seeds of Punica granatum (Pomegranate). J Nat Prod. 2004;67(1):206-8.

34. Ei-Toumy SAA, Marzouk MS, Rauwals HW. Ellagi-and gallotannins from Punica granatum heart wood. J Pharmazie. 2001;56(10):823-4.

35. Tiwari S. Punica granatum 'A Swiss Army Knife' in the field of ethnomedicine. J Nat Prod. 2012;5:4.

36. Tanaka T, Nonaka G, Nishioka I. Punicafolin an ellagitannin from the leaves of Punica granatum. Phytochemistry. 1985;24(9):2075-8

37. Elfalleh W, Nasri N, Marzougui N, Thabti I, M`Rabet A, Yahya Y, et al. Physicochemical properties and DPPH-ABTS scavenging activity of some local pomegranate ecotypes. Int J Food Sci Nutr. 2009;60(2);925-38.

38. Guo C, Wei J, Yang J. Pomegranate juice is potentially better than apple juice in improving antioxidant function in elderly subjects. Nutr Research. 2008;28(2):72-7.

39. Ricci D, Giamperi L, Bucchini A, Fraternale D. Antioxidant activity of Punica grantum fruits. Fitoterapia. 2006;77(4):310-2.

40. Amin ARMR, Kucuk O, Khuri FR, Shin DM. Perspectives for cancer prevention with natural products. J Clin Oncol. 2009;27(16):2712-25.

41. Sturgeon SR, Ronnenberg AG. Pomegranate and breast cancer: Possible mechanisms of prevention. Nutr Rev. 2010;68(2):122-8.

42. Albrecht M, Jiang J, Kumi-Diaka J, Lansky EP, Gommersall LM, Patel A, et al. Pomegranate extracts potently suppress proliferation, xenograft growth and invasion of human prostate cancer cells. J Med Food. 2004;7(3):274-83.
43. Burapadaja S, Bunchoo A. Antimicrobial activity of tannins form Terminalia citrine. Planta Medica. 1995;61(4):365.

44. Mehta R, Lansky EP. Breast cancer chemopreventive properties of pomegranate (Punica granatum) fruit extracts in a mouse mammaryorgan culture. Eur $J$ Cancer Prev. 2004;13(4):345-8.

45. Azzouz MA, Bullerman LB. Comparative antimycotic effects of selected herbs, spices, plant components and commercial antifungal agents. J Food Prot. 1982;45(14):1298.

46. Gopalakrishnan S, Benny PJ. Invitro antimicrobial properties of Punica granatum extract on bacteria causing urinary tract infections. Indian Drugs. 2009;46(9):1722.

47. El-Sherbini GM, Ibrabim KM, EISherbiny ET, Abdul-Hady NM, Morsy TA Efficacy of Punica granatum extract on in vitro and invivo control of Trichomonas vaginalis. J Egypt Soc Parasitol. 2010;40(1):229-44.

48. Endo EH, Cortez DAG, Veda-Nakamura T, Nakamura CV, Filho BPD. Potent antifungal activity of extracts and pure compound isolated form pomegranate peels and synergism with fluconazole against Candida albicans. Res Microbiol. 2010;161(7):534-40.

49. Menezes SM, Cordeiro LN, Viana GS. Punica granatum (Pomegranate) extract is active against dental plaque. J Pharmacother. 2006;6(2):72-92.

50. Shukla M, Gupta K, Rasheed Z, Khan KA, Haqqi TM. Consumption of Hydrolyzable tannins-rich pomegranate extract suppresses inflammation and joint damage in rheumatoid arthritis. Nutrition. 2008;24(7-8):733-43.

51. Adams LS, Sreeram NP, Aggarwal BB, Takada Y, Sand D, Heber D. Pomegranate juice, total pomegranate ellagitannins punicalagin suppress inflammatory cell signaling in colon cancer cells. J Agri Food Chem. 2006;54(3):980-5.

52. Aviram M, Rosenblat D, Gitini S, Nitecki A, Hoffman A, Dornfeld L, et al Pomegranate juice consumption for 3 years by patients with carotid artery stenosis reduces common carotid intima-media thickness, blood pressure and LDL oxidation. Clin Nutri. 2004;23(3):423-33.

53. Rosenblat M, Hayek T, Aviram M. Antioxidative effects of pomegranate juice (PJ) consumption by diabetic patients on serum and on macrophage. Atherosclerosis. 2006;187(2):363-71.

54. De Nigris F, Balstrieri ML, Williams-Ignarro S, Armiento FPD, Fiorito C, Ignarro $\mathrm{LJ}$, et al. The influence of pomegranate fruit extract in comparison to regular pomegranate juice and seed oil on nitric oxide and arterial function in obese zucker rats. Nitric oxide. 2007;17(1):50-4.

55. De Nigris F, Williams-Ignarro S, Sica V, Lerman LO, D'Armiento FP, Byrns RE et al. Effects of a pomegranate fruit extract rich in punicalagin on oxidativesensitive genes and eNOs activity at sites of perturbed shear stress and atherogenesis. Cardiovascular Research. 2007;73(2):414-23.

56. Aviram M, Volkava NR, Voleman M, Dreher, Reddy MK, Ferreira D, et al Pomegranate phenolics from the peels, arils and flowers are antiatherogenic. Studies invivo in atherosclerotic apolipoprotein e-deficient (EO) mice and invitro in cultured macrophage and lipoproteins. J Agric Foodchem. 2008;56(3):114857.

57. Rosenblat M, Volkova N, Coleman R, Aviram M. Pomegranate by product administration to apolipoprotein E-deficient mice attenuates atherosclerosis is development as a result of decreased macrophage oxidative stress reduced cellular uptake of oxidized low-density lipoprotein. J Agri Food chem. 2006;54(5):1928-35.

58. Zelepukha SI, Sagun TS. Antimicrobial properties of several anthocyanins. Tr Uses semin. Biol Activ Veshchestuam Pladov Yagod. 1975;82:39090.

59. Kumar S, Maheshwari KK, Singha V. Central nervous system activity of acute administration of ethanol extract of Punica granatum L. seeds in mice. Indian J Experi Biol. 2008;46(12):811-6.

60. Katz SR, Newman RA, Lansky. Punica granatum: Heuristic treatment for diabetes mellitus. J Med Food. 2007;10(2):213-7.

61. Huang TH, Peng G, Kota BP, Li GQ, Yamahara J, Roufogalis BD, et al. Antidiabetic action of Punica granatum flower extract. Activation of PPARgamma and identification of an active component. Toxicol Applied Pharmacol. 2005;207(2):160-9.

62. Huang FH, Yang Q, Harada M, Li Ggq, Yamahara J, Roufogalis BD, et al Pomegranate flower extract diminishes cardiac fibrosis in zucker diabetic fatty rats: Modulation of cardiac endothelin-1 and nuclear factor-kappa pathways. $J$ Cardiovasc Pharmacol. 2005;4(6):856-62.

63. Li Y, Qi Y, Huang THW, Yamahara J, Roufogalis BD. Pomegranate flower: A unique traditional antidiabetic medicine with dual PPAR- $\alpha-\gamma$-activator properties. Diabetes Obes Metab. 2008;10(1):10-7. 
64. Bagri P, Ali M, Aeri V, Bhowmik M, Sultana S. Antidiabetic effect of Punica granatum flowers: Effect on hyperlipidemia, Pancreatic cells lipid peroxidation and antioxidant enzymes in experimental diabetes. Food Chem Toxicol 2009b;47(1):50-4.

65. Pacheco-Palencia LA, Noratto G, HingoraniL, Talcott ST, Martens Tlacott SU. Protective effects of standardized pomegranate (Punica granatum) polyphenolic extract in ultraviolet-irradiated human skin fibroblasts. J Agric Food Chem. 2008;56(18):8434-41.

\section{GRAPHICAL ABSTRACT}

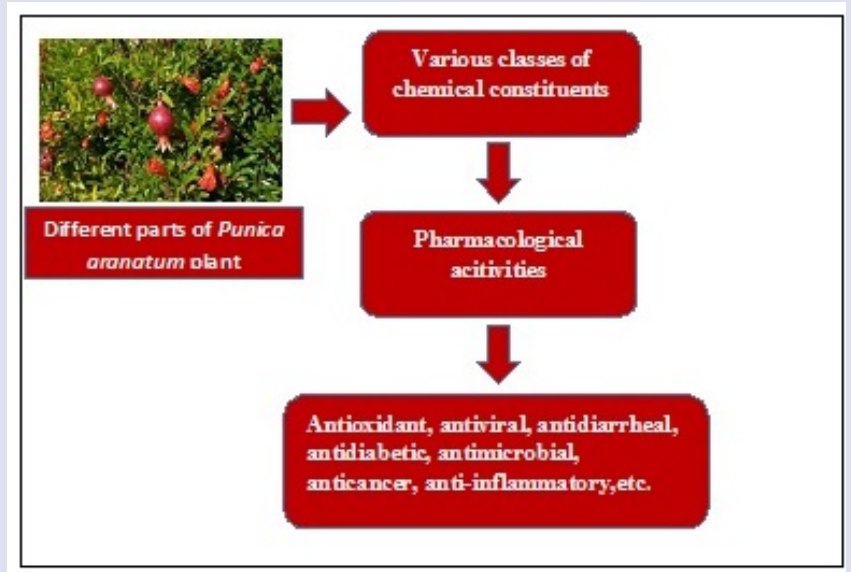

66. Yoshimura M, Watanabe $Y$, Kasai K, Yamakoshi J, Koga T. Inhibitory effect of an ellagic acid-rich pomegranate extract on tyrosinase activity and ultravioletinduced pigmentation. Biosci Biotechnol Biochem. 2005;69(12):2363-73.

67. Lai S, Zhou Q, Zhang Y, Shang J, Yu T. Effects of Pomegranate tannins on experimental gastric damages. Zhongguo Zhong Yao ZA Zhi. 2009;34(10):12904.

68. Pillai NR. Antidiarrheal activity of Punica granatum in experimental animals. Int J Pharmacol. 1992;30(3):201-4.

\section{SUMMARY}

- This attempt is made to present an overview of phytochemical and pharmacological activities of plant Punica granatum.

- In the Ayurvedic system of medicine, Punica granatum is known as "A pharmacy unto itself"

- $P$. granatum is used in different systems of medicine for treating a variety of ailments in humans.

- The chemical composition of the fruit and other plant parts possess an array of therapeutic properties.

- P. granatum has been reported with various pharmacological activities like antioxidant, antimicrobial, antiviral, antidiabetic, anticancer, Alzheimer's disease, etc., due to the presence of bioactive compounds.

\section{ABOUT AUTHORS}

Janani Jacob is a Research Scholar, Karpagam Academy of Higher Education, Coimbatore, India.

Dr. Rajiv $\mathrm{P}$ is an Assistant Professor, Department of Biotechnology, Karpagam Academy of Higher Education, Coimbatore, India.

Dr. Gopalan R is the Head of Department of Botany, Karpagam Academy of Higher Education, Coimbatore, India.

Dr. Lakshmanaperumalsamy $\mathrm{P}$ is a Former Registrar, Karpagam Academy of Higher Education, Coimbatore, India.

Cite this article: Janani J, Rajiv P, Gopalan R, Lakshmanapermalsamy P. An Overview of Phytochemical and Pharmacological Potentials of Punica granatum L. Pharmacog J. 2019;11(5):1167-71. 